\title{
An Empirical Study of Factors Affecting Poverty Level Among Albanian Families
}

\author{
Lindita Mukli \\ "Aleksandër Moisiu" University of Durrës \\ linditamukli@gmail.com \\ Rezarta Mersini \\ "Aleksandër Moisiu" University of Durrës \\ rmersini@hotmail.com
}

\section{Doi:10.5901/mjss.2013.v4n11p646}

\section{Abstract}

Poverty threshold defined as the minimum expenditure basket of food, other known as consumption, provides an adult approximately 2,100 calories per day, in addition to a multiplier of other essential goods. The income needed to meet this minimum threshold is about 1.5 Euros per adult a day, or approximately 50 Euros per adult a month. Population having income values below this threshold is considered to be living in poverty. Literature suggests that a country's economic development, migration, welfare, education of family members, family composition, economic assistance, rural or urban development, are important factors affecting poverty threshold value. The purpose of this study is to analyze the impact of employment status, family composition, education of parents, migration, and family residential area on poverty.

Keywords: Threshold of poverty, education, migration, consumption basket, poverty.

\section{Introduction}

Poverty, as an unacceptable physiological and social deprivation, is defined as an economic condition of lacking stable means to meet basic necessities, in other words, food, water, shelter, education and healthcare (World Bank, 2000). Poverty threshold, or the Poverty line, known as the minimum adequate level of income to meet basic requirements, is officially higher in developed countries than in developing countries (Hagenaars and De Vos, 1988).

The common international poverty threshold has in the past has been estimated 1 American Dollar per adult a day, while in 2008, the World Bank revised the purchasing-power parity (PPP) figure of 1.25 American Dollars (World Bank, 2005) to 2 American Dollars or 1.5 Euros per adult a day (approximately 50 Euros per adult a month).

Purchasing-power parity or PPP estimates the adjusted amount needed to facilitate international comparisons of income due to volatile exchange rates in different countries. Poverty headcount ratio at 2 American Dollars (1.5 Euros) PPP is $4.25 \%$ (World Bank, 2008), which means that in $2008,4.25 \%$ of the population in Albania had a daily income of less than 2 American Dollars or 1.5 Euros to meet basic necessities.

Poverty headcount ratio at rural poverty line in Albania is $14.6 \%$ of rural population. On the contrary, poverty headcount ratio at urban poverty line is $10.1 \%$ of urban population (World Bank, 2008).

Albania's transition to a democratic society and market-based economy has proved to be very challenging in terms of increased poverty rates due to high rates of unemployment. Rapid economic growth, structural reforms and implementation of policies were among the different Albanian governments strategies to continously reduce poverty level since 2002.

Poverty reduction was a strategic priority of government, as it appears in National Strategy for Development and Integration (2007-2013). Government policies are reflected in the Strategy for Social Inclusion (2007-2013), the Strategy of Social Protection (2007-2013) and the Strategy on Employment and Vocational Training 2007-2013 as well, whose scope is to build an inclusive society for both urban and rural areas (UNDP Albania, 2013).

Globally, extreme poverty continues to be a rural phenomenon rather than urban (Anriquez and Stamoulis, 2007). It is also suggested that economic growth policies are crucial to poverty reduction strategies (The International Bank for Reconstruction and Development, 2002). Kenworthy (1999) discusses that social welfare policies also help to reduce poverty even when indirect. 
Family composition does strongly impact poverty reduction as reflected in the findings of Atkinson (1992). World Bank Report (2007) states that larger households account for much higher incidence of poverty and the risk of poverty is much lower in more educated families. Education attainment and work experience are seen as very effective in poverty reduction in transition countries (Njong, 2010; Chaudhry et.al, 2010).

In low income countries, remittances are seen as very important sources of poverty reduction (McLeod and Molina, 2005). As far as remittances from migration is concerned, some of the most dramatic reductions in poverty were observed among the rural population in the Mountain areas and urban population in Tirana and some major cities in Albania. There is clear evidence that Tirana and the Mountain rural regions are the areas where the largest increases in the share of households receiving remittances have been observed (World Bank Report, 2007).

\section{Data, Methods and Results}

Survey Monkey Online Tool was used to gather structured data from 39 respondents. Further analysis has been conducted through SPSS statistical software.

\subsection{Demographic Data Frequencies}

In Table 1, respondents demographic profile was generated by means of Frequencies taking into consideration gender, age, marital status, employment status, education level and residental area.

Table 1. Respondents Profile

\begin{tabular}{|c|c|c|c|c|c|}
\hline & & Frequency & Percent & Valid Percent & Cumulative Percent \\
\hline \multirow{3}{*}{ Gender } & Female & 17 & 84 & 43,59 & 43,59 \\
\hline & Male & 22 & 1,09 & 56,41 & 100,00 \\
\hline & Total & 39 & 1,92 & 100 & \\
\hline \multirow{5}{*}{ Age } & $18-23$ yrs & 30 & 1,5 & 76,9 & 76,9 \\
\hline & $24-29 \mathrm{yrs}$ & 3 & , 1 & 7,7 & 84,6 \\
\hline & $30-35 \mathrm{yrs}$ & 3 & 1 & 7,7 & 92,3 \\
\hline & $>36$ yrs & 3 & 1 & 7,7 & 100,0 \\
\hline & Total & 39 & 1,9 & 100,0 & \\
\hline \multirow{4}{*}{ Marital Status } & Single & 30 & 1,5 & 76,9 & 76,9 \\
\hline & Engaged & 3 & 1 & 7,7 & 84,6 \\
\hline & Married & 6 & ,3 & 15,4 & 100,0 \\
\hline & Total & 39 & 1,9 & 100,0 & \\
\hline \multirow{3}{*}{ Employment Status } & No & 26 & 1,3 & 66,7 & 66,7 \\
\hline & Yes & 13 & 6 & 33,3 & 100,0 \\
\hline & Total & 39 & 1,9 & 100,0 & \\
\hline \multirow{4}{*}{ Education Level } & Bachelor Degree & 29 & 1,4 & 74,4 & 74,4 \\
\hline & Master Degree & 9 & ,4 & 23,1 & 97,4 \\
\hline & Philosophy Degree & 1 & 0 & 2,6 & 100,0 \\
\hline & Total & 39 & 1,9 & 100,0 & \\
\hline \multirow{3}{*}{ Residental Area } & Rural Area & 8 & ,4 & 20,5 & 20,5 \\
\hline & Urban Area & 31 & 1,5 & 79,5 & 100,0 \\
\hline & Total & 39 & 1,9 & 100,0 & \\
\hline
\end{tabular}

\subsection{Impact of Employment Status on Income}

Monthly Income is selected over other dependent variables as a poverty indicator. By this ratio: (monthly income) / 
(number of family members) * (average number of days/month), a daily income value per individual can be obtained. Compared to the minimum poverty threshold, not a much higher difference has been observed. Moreover, reliability of Monthly Income scale variable is measured. Cronbach's Alpha coefficient equals 1,000. Therefore maximum internal consistency reliability is confirmed. After Cronbach Test, Linear Regression is conducted to show whether there exists a relationship of employment status and income or not. Regression model is fit, given high values of $R=.885$ and $R$ Square $=$. 783. Employment status is statistically significant at $p=.000$. This reconfirms previous findings that employment does reduce poverty, in other words it helps increase of monthly income in order for a family to survive.

\subsection{Impact of Family Composition, Education Level on Income}

Family composition impact on Monthly Income has been also tested. Regression model is not fit (for $\mathrm{R}=.039$ and $\mathrm{R}$ Square $=.001$ ). Family Composition is not statistically significant at $p=.816$. The reason behind this result might relate to the impact of more powerful factors: remittances from migration and expenditure based on residental living area. However, using multivariate regression, Family Composition and Education Level have been tested over Monthly Income. Education attainment alone is found to be a very powerful factor affecting poverty reduction even in large composition families as confirmed by Njong (2010) and Chaudhry et.al, (2010). Multivariate model testing Family Composition and Education Level simultaneously over Monthly Income, is considerably improved with $\mathrm{R}=.684$ and $\mathrm{R}$ Square $=.468$. These two paired factors do impact income at $p=.000$.

\subsection{Impact of Father's Education Level, Mother's Education Level on Income}

The impact of education attainment level among parents, namely father and mother, on poverty reduction (increased monthly income) has been analyzed. Father's education level alone does not seem to be a significant factor over monthly income as shown from Linear regression (with $p=.997$ ) and Bivariate Correlation Pearson coefficient of very small value $(r=.001)$. Additionally Mother's Education Level is neither statistically significant at $p=.257$ and $r=-.186$ which a fairly medium correlation which suggests not high impact on Income. If father's and mother's education level istested as a pair of independent variables over income (poverty reduction), improved regression coefficient can be obtained.

\subsection{Impact of Migration on Income Total}

Remittances from migrated family members is seen as a crucial factor affecting poverty reduction in low income and transition countries. Income Total refers to the total monthly income taking into account remittances as well. High effect of migration on poverty reduction and increased monthly income is observed in this study. The regression model is wellfitting $(R=.950$, $R$ Square =. 903). Thus, migration is a highly statistically significant factor at $p=.000$. The finding confirms (McLeod and Molina, 2005).

\subsection{Impact of Family Residental Area on Income}

Residental areas, namely rural and urban areas are believed to impact the monthly income and affect poverty reduction. Means analysis is run on residental area groups to observe if there is any difference between Rural Area and Urban Area groups affecting Monthly Income. As seen in Table 2, there is not much difference of Mean values of both groups.

Table 2. Means - Residental Area and Income

\begin{tabular}{|l|c|c|c|}
\hline Residental Area & Mean & N & Std. Deviation \\
\hline Rural Area & 625,8750 & 8 & 514,96170 \\
\hline Urban Area & 678,4839 & 31 & 472,15025 \\
\hline Total & 667,6923 & 39 & 474,66538 \\
\hline
\end{tabular}

A more detailed Means Analysis has been conducted adding up Education Level as an independent variable (see Table 3). The Std. Deviation column indicates that individuals who hold Bachelor Degree and live in rural areas, vary more widely around their monthly incomes than similarly educated individuals residing in urban areas. The same can be observed on individuals who hold a Master Degree. Its is shown that there is a significant difference of incomes in rural 
and urban areas, regardless of the same education level attained. This is to be explained by the gap of wage rates in urban versus rural areas. Therefore, educated individuals who are resident in urban areas tend to be less poorer than similarly educated individuals living in rural areas.

Table 3. Means - Residental Area, Education Level and Income

\begin{tabular}{|c|l|c|c|c|}
\hline Residental Area & Education Level & Mean & N & Std. Deviation \\
\hline \multirow{4}{*}{ Rural Area } & Bachelor Degree & 714,5714 & 7 & 485,75435 \\
\cline { 2 - 5 } & Master Degree & 5,0000 & 1 &. \\
\cline { 2 - 5 } & Total & 625,8750 & 8 & 514,96170 \\
\hline \multirow{4}{*}{ Urban Area } & Bachelor Degree & 908,7727 & 22 & 292,03815 \\
\cline { 2 - 5 } & Master Degree & 129,1250 & 8 & 351,48397 \\
\cline { 2 - 5 } & Philosophy Degree & 7,0000 & 1 & \\
\cline { 2 - 5 } & Total & 678,4839 & 31 & 472,15025 \\
\hline \multirow{5}{*}{ Total } & Bachelor Degree & 861,8966 & 29 & 348,82613 \\
\cline { 2 - 5 } & Master Degree & 115,3333 & 9 & 331,37630 \\
\cline { 2 - 5 } & Philosophy Degree & 7,0000 & 1 & \\
\cline { 2 - 5 } & Total & 667,6923 & 39 & 474,66538 \\
\hline
\end{tabular}

\section{Conclusions}

Poverty reduction is affected by employment status, education level of the respondent, migration, residental area. Despite previous findings, parents' education level an family composition are not statistically significant, thus they do not seem to be important factors in improving poverty levels. These results might be explained by migration remittances that help poverty reduction.

Education level highly differs in individuals residing in urban areas rather than rural ones. It is also shown that remittances flow mostly towards rural areas strongly helps poverty eradication.

Limitations include limited sample size of online survey participants. Future empirical research could focus on the impact of these factors on a larger population, considering other demographic variables.

\section{References}

Anriquez, G. and Stamoulis, K. (2007). "Rural Development and Poverty Reduction: Is Agriculture Still the Key?". Agricultural Development Economics Division. The Food and Agriculture Organization of the United Nations. ESA Working Paper No.07-02. Retrieved from www.fao.org/es/esa

Atkinson, A.B. (1992). "Measuring poverty and differences in family composition". Economica. New Series. Vol. 59, No. 233, p. 1-16.

Chaudhry, I. S., et.al, (2010). "Does Education Alleviate Poverty? Empirical Evidence from Pakistan". International Research Journal of Finance and Economics. ISSN 1450-2887, Issue 52.

Hagenaars, A. \& De Vos, K. (1988). "The Definition and Measurement of Poverty". Journal of Human Resources. The International Bank for Reconstruction and Development 2002 Report (2013). Retrieved from https://openknowledge.worldbank.org/browse

Kenworthy, L. (1999). "Do social-welfare policies reduce poverty? A cross national assessment". The University of North Carolina Press. Social Forces, 77(3): 1119-39.

McLeod, D. and Molina, J. (2005). "Remittances, inequality and poverty reduction: Some tests for Latin America". October 2005 LACEA Meetings Paper Proceedings, AUP Paris, France.

Njong, A.M. (2010). "The effects of educational attainment on poverty reduction in Cameroon". Journal of Education Administration and Policy Studies. Vol.2 (1), p. 001-008.

Ravallion, M. (1992). "Poverty freak: A Guide to Concepts and Methods". Living Standards Measurement Papers, The World Bank, p. 25.

UNDP Human Development Indicators Albania Report (2013). Retrieved from http://hdrstats.undp.org/en/countries/profiles/ALB.html

World Bank's 2000 World Development Report (2013). Retrieved from http://econ.worldbank.org/wbsite/external/extdec/extresearch lextwdrs/0,,contentmdk:20227703 pagepk:478093 pipk:477627 thesitepk:477624,00.html

World Bank's 2005 World Development Indicators (2013). Retrieved from http://data.worldbank.org/indicator/si.pov.2day/countries lal?display=default

World Bank's 2007 Report (2013). Retrieved from http://econ.worldbank.org/wbsite/external/extdec/extresearch/extwdrs/0,,contentmdk: 20227703 pagepk:478093 pipk:477627 thesitepk:477624,00.html

World Bank's 2008 World Development Indicators (2013). Retrieved from http://data.worldbank.org/indicator/si.pov.2day/countries lal?display=default 